Article

\title{
Low-Carbon Binder for Cemented Paste Backfill: Flowability, Strength and Leaching Characteristics
}

\author{
Jingping Qiu ${ }^{1,2}$, Yingliang Zhao ${ }^{1,2, *}$, Hui Long ${ }^{3}$, Zhenbang Guo ${ }^{1,2}$, Jun Xing ${ }^{1,2}$ and \\ Xiaogang Sun ${ }^{1,2}$ \\ 1 College of Resources and Civil Engineering, Northeastern University, Shenyang 110819, China; \\ qiujingping@mail.neu.edu.cn (J.Q.); WCPP2019@163.com (Z.G.); xingjun@mail.neu.edu.cn (J.X.); \\ sunxiaogang@mail.neu.edu.cn (X.S.) \\ 2 Science and Technology Innovation Center of Smart Water and Resource Environment, \\ Northeastern University, Shenyang 110819, China \\ 3 China Railway Construction Heavy Industry Co. Ltd., Changsha 410100, China; longhei1234566@163.com \\ * Correspondence: vigmore_zhao@hotmail.com
}

Received: 5 September 2019; Accepted: 10 November 2019; Published: 15 November 2019

\begin{abstract}
Blast furnace slag was used as the main raw material to prepare the alkali activated slag (AAS), a low-carbon binder, for cemented paste backfill (CPB). The optimum parameters for preparing the AAS binders using an orthogonal experiment were obtained. Under the optimum conditions ( $\mathrm{NaOH}$ content was 3 wt. \%, Ordinary Portland cement (OPC) content was 7 wt. \%, and gypsum dosage was $4 \mathrm{wt}$. \%), the 28 days compressive strength of the binder was $29.55 \mathrm{MPa}$. The flow ability of the fresh CPB slurry decreased with solid content due to the increased yield stress, while the flow ability increased when rising the binder dosage. A predictive model for the compressive strength of CPB samples was reached through multivariate analysis and the $\mathrm{R}^{2}$ values were higher than 0.9 . Sensitivity analysis showed that the solid content is the most important parameter which influences on the development of the CPB strength with a correlation coefficient of 0.826 . From the Toxicity Characteristic Leaching Procedure (TCLP) tests, the leaching concentrations of $\mathrm{Pb}$ and $\mathrm{Cd}$ were below the threshold. As a result, the AAS has potential application as an alternative binder and cemented paste backfill.
\end{abstract}

Keywords: backfill; alkali activated slag; water film; compressive strength; TCLP

\section{Introduction}

Mining is the foundation of modern industry. Advanced mining industry is the need of developing the metallurgical and all other industries at a high speed and realizing the modernization of agriculture, national defense and science and technology. However, while making irreplaceable contribution to modern industrial civilization, mining also causes serious damage to ecological environment. Especially, the accumulation of tailings occupies a large amount of land and causes landslides and debris flows, resulting in the destruction or damage of vegetation to varying degrees and destroy the ecological balance of the mining area and even the surrounding areas. Therefore, the comprehensive utilization of tailings is an inevitable choice to promote the sustainable development of China's mining industry and promote the construction of green mines.

With the gradual transfer of mining to deep ore body, deep well mining is faced with the problem of high in-situ stress. As a result, cemented back filling (CPB), which uses ordinary Portland cement (OPC) as main binder materials, has become the preferred, safest and most productive mining method for deep well mining. It has been reported that the production of OPC contributes to at least $8 \%$ of global $\mathrm{CO}_{2}$ emissions because its production requires high kiln temperature $\left(1450-1550{ }^{\circ} \mathrm{C}\right)$ which 
could lead to limestone decomposition [1]. As well, the manufacturing process consumes a large amount of non-renewable resources, such as limestone, and causes significant over-exploitation of natural reserves. Therefore, it is urgent to develop an alternative binder with lower environmental and energy costs.

Alkali activated materials (AAM) have been widely identified as a "sustainable cement binder", using a silica- and alumina-containing solid precursor mixing with an alkali source at ambient or elevated temperature [2]. Since many industry by-products, such as blast furnace slag and fly ash can be used as the raw materials, AAM is considered as an alternative to the OPC [3], which has been used in many industry aspects including CPB. Blast furnace slag (BFS) seems to be widely used in China due to the rapidly developed steel industries in recent years [4]. Jiang et al. [5] used blast furnace slag as aluminosilicate precursor and sodium silicate/sodium hydroxide as alkali activator to prepare $\mathrm{CPB}$ binders and explored the solid content, binder dosage, activator to binder ratio, sodium silicate to sodium hydroxide ratio, and curing temperature on fresh and hardened properties of CPB mass. The results showed that for a given backfill recipe and curing time, CPB matrix using alkali activated slag provided far better workability and compressive strength performance than OPC-CPB matrix. $G$ et al. [6] investigated the strength and microstructural development of full and coarse sulphidic tailings CPB using sodium silicate activated slag as binder. The results proved that sodium silicate activated slag with varying silicate modulus for both full and coarse sulphidic tailings produced 1.5-3.5-fold compressive strengths in the long-term compared to OPC samples. Cihangir et al. [7] used alkali-activated neutral and acidic blast furnace slags blended with aqueous sodium silicate and sodium hydroxide as alternative binders to OPC for $\mathrm{CPB}$ of high-sulphide mill tailings. Poor mechanical performance was observed in the CPB samples prepared from OPC. However, CPB samples of alkali activated slag were found to produce remarkably higher strengths (1.54-4.74 MPa at 360 days) and stability over 360 days of curing. While Zhao Y. et al. [8] using a new binder called Mine Cement (MC), mainly consisting of blast furnace slag, OPC, cement kiln dust, gypsum and limestone, for mine back filling, which shown good feasibility. All these studies revealed the feasibility of using alkali activated materials as a new binder in the CPB and good performance was observed.

In this study, orthogonal test was used to explore the effect of sodium hydroxide content, OPC and gypsum dosage on the properties of alkali activated binder and determine the mix proportion the binder to be used in CPB. The rheological and strength properties including multivariate analysis and sensitivity analysis were then studied. TCLP tests were used to explore the leaching properties of the prepared CPB samples.

\section{Materials and Methods}

\subsection{Materials}

Materials used in this research include blast furnace slag (BFS), provided by Hanwang group Fushun, China. Ordinary Portland cement (OPC) and gypsum, obtained from Jinfeng Materials Co., Ltd. in Kaifeng, China. The chemical compositions of above-mentioned materials are presented in Table 1. Fine aggregate used was mine tailings (MT) which is collected from an iron mine located in the Fushun, China. MT are dried at $105^{\circ} \mathrm{C}$ for $24 \mathrm{~h}$ before used. The particle size distribution of MT could be found in the Figure S1 in supplementary materials. The leaching concentrations of heavy metals in original tailings are shown in Table 2.

Sodium hydroxide $(\mathrm{NaOH})$ solution is used as alkaline activator because it is widely available and less expensive. $\mathrm{NaOH}$ pellets of $98 \%$ purity are dissolved in distilled water to obtain $\mathrm{NaOH}$ solution of required molarity and stored at room temperature for $24 \mathrm{~h}$ before its use. 
Table 1. Main components of raw materials/wt. \%.

\begin{tabular}{ccccccccc}
\hline Materials & $\mathbf{C a O}$ & $\mathrm{SiO}_{2}$ & $\mathrm{Al}_{2} \mathbf{O}_{\mathbf{3}}$ & $\mathbf{M g O}$ & $\mathbf{K}_{\mathbf{2}} \mathbf{O}$ & $\mathbf{F e}_{2} \mathbf{O}_{3}$ & $\mathbf{N a}_{\mathbf{2}} \mathbf{O}$ & BET Surface Area $\left(\mathbf{m}^{2} / \mathbf{k g}\right)$ \\
\hline BFS & 48.83 & 35.46 & 8.99 & 3.07 & 0.87 & 0.63 & 0.51 & 567.87 \\
OPC & 57.21 & 21.65 & 5.84 & 4.79 & 0.45 & 1.77 & 0.86 & 586.22 \\
Gypsum & 38.85 & 0.29 & 0.01 & 2.32 & 0 & 0.06 & 0 & 521.09 \\
\hline
\end{tabular}

Table 2. Leaching concentration of heavy metals in mine tailings.

\begin{tabular}{ccc}
\hline Heavy Metals & Leaching Concentration $(\mathrm{mg} / \mathrm{L})$ & GB 16889-2008 [9] $(\mathrm{mg} / \mathrm{L})$ \\
\hline $\mathrm{Cu}$ & $0.55 \pm 0.03$ & 40.00 \\
$\mathrm{~Pb}$ & $0.65 \pm 0.06$ & 0.25 \\
$\mathrm{Zn}$ & $2.68 \pm 0.12$ & 100.00 \\
$\mathrm{Cd}$ & $0.39 \pm 0.04$ & 0.15 \\
\hline
\end{tabular}

\subsection{Methods}

Factorial design was used to determine the optimal binder combination to improve the efficiency and properties of CPB samples. Orthogonal array, L9 $\left(3^{3}\right)$ (Table 3) to represent a full factorial experiment were used in the present study (Table 2). The component variables for each of the mixes (T-1 to T-9) are presented in Table 4 . The effect of $\mathrm{NaOH}$ content, OPC dosage and content of gypsum on the 28 days compressive strength of binder samples were analyzed in this approach by conducting the range analysis and calculating the $\mathrm{K}$ value and range value $(\mathrm{R})$. The most prominent factor has the highest $R$ value. The mixture ratio was selected based on the range analysis.

Table 3. Factor level table of orthogonal test.

\begin{tabular}{cccc}
\hline Factors & Level 1 & Level 2 & Level 3 \\
\hline A: NaOH content (wt. \%) & 3 & 4 & 5 \\
B: OPC dosage (wt. \%) & 7 & 8 & 9 \\
C: gypsum content (wt. \%) & 4 & 5 & 6 \\
\hline
\end{tabular}

Table 4. L9 $\left(3^{3}\right)$ orthogonal array.

\begin{tabular}{ccccc}
\hline No. $\mathbf{T}-\mathbf{j}$ & A & B & C & Compressive Strength/MPa \\
\hline $\mathrm{T}-1$ & $1(3 \%)$ & $1(7 \%)$ & $1(4 \%)$ & 29.55 \\
$\mathrm{~T}-2$ & 1 & $2(8 \%)$ & $2(5 \%)$ & 26.71 \\
$\mathrm{~T}-3$ & 1 & $3(9 \%)$ & $3(6 \%)$ & 22.00 \\
$\mathrm{~T}-4$ & $2(4 \%)$ & 1 & 2 & 25.91 \\
$\mathrm{~T}-5$ & 2 & 2 & 3 & 22.66 \\
$\mathrm{~T}-6$ & 2 & 3 & 1 & 24.28 \\
$\mathrm{~T}-7$ & $3(5 \%)$ & 1 & 3 & 26.75 \\
$\mathrm{~T}-8$ & 3 & 2 & 1 & 25.64 \\
$\mathrm{~T}-9$ & 3 & 3 & 2 & - \\
\hline $\mathrm{K}_{\mathrm{j} 1}$ & 78 & 82 & 79 & - \\
$\mathrm{K}_{\mathrm{j} 2}$ & 72 & 75 & 74 & - \\
$\mathrm{K}_{\mathrm{j} 3}$ & 74 & 67 & 71 & - \\
$\mathrm{R}$ & 1.8 & 4.8 & 2.7 & - \\
\hline Optimal level & $\mathrm{A} 1$ & $\mathrm{~B} 1$ & $\mathrm{C} 1$ & - \\
\hline \multicolumn{5}{c}{ B $>\mathrm{C}>\mathrm{A}$} \\
Order & A1B1C1 & \\
\hline \multicolumn{5}{c}{}
\end{tabular}

To prepare the samples, BFS, OPC, gypsum and MT were dry mixed for 5 min to obtain a homogenous mixture. $\mathrm{NaOH}$ solution was then poured into the mixture and mixed for another $5 \mathrm{~min}$. After that, the pastes were poured into molds with diameter of $50 \mathrm{~mm}$ and height of $100 \mathrm{~mm}$ and vibrated for $2 \mathrm{~min}$ to remove air bubbles and then sealed in plastic bags and cured at room temperature. 
After $24 \mathrm{~h}$, demolded and cured at $23{ }^{\circ} \mathrm{C}$ and $90 \%$ relative humidity until testing. It should be noted that MT was introduced in the samples, expect the samples used for orthogonal tests in Table 4.

Compressive strength tests were performed by using a computer-controlled mechanical press with a loading capacity of $50 \mathrm{kN}$ and a displacement loading speed of $1 \mathrm{~mm}$ per minute, according to the ASTM D2166/D2166M-16 [10] standard. For each mix formulation, triplicate tests were conducted and the average values were recorded.

The fragments after compressive strength test were collected and impregnated using isopropanol to stop the hydration process and then dried under vacuum at $40^{\circ} \mathrm{C}$. After that, the treated fragments were grounded to fine powder. X-ray diffraction (XRD) analysis was carried out using an $X^{\prime}$ Pert Pro XRD (Philips, Amsterdam, The Netherlands) at a scanning rate of $0.1 \mathrm{deg} \cdot \mathrm{s}^{-1}$ in the $2 \theta$ range of $10^{\circ}$ to $70^{\circ}$.

The flow spread of the fresh $\mathrm{CPB}$ samples was determined by the mini-slump test following the ASTM C1437-15 [11], using a copper cone with standard dimensions of height of $50 \mathrm{~mm}$ and $70 \mathrm{~mm}$ top and $100 \mathrm{~mm}$ base diameters. The CPB samples were filled into the cone and then the cone was lifted vertically. The diameters of the resulted paste spread were then measured along two perpendicular directions.

The yield stress of the fresh CPB samples were measured using a Haake rheometer with a four-blade vane at a low rotational rate $(0.2 \mathrm{rpm})$ due to the accuracy [12].

The water film thickness (WFT) around particles in fresh CPB slurry can be obtained from the following equations

$$
\mathrm{WFT}=\frac{u_{\mathrm{w}}-u_{\mathrm{s}}}{A_{\mathrm{s}}}
$$

where $u_{\mathrm{w}}$ is the water ratio of the CPB mix (the ratio of the volume of water to the solid volume of all the particles). The voids ratio $u_{\mathrm{s}}$ can be obtained as $u_{\mathrm{w}}=(1-\Phi) / \Phi$, where $\Phi$ is the packing density of all the particles. $A_{\mathrm{s}}$ is the specific surface area of all the solid particles.

The leaching properties of the CPB samples were examined by ICP-OES (iCAP 7200, Thermofisher, Waltham, MA, USA) according to the standard of HJ/T 300-2007 [13]. During this process, $60 \mathrm{~g}$ tailings or $\mathrm{CPB}$ samples were dried at $105^{\circ} \mathrm{C}$ for $24 \mathrm{~h}$, before mixing with the extraction solution (a mixture of $1 \mathrm{~L}$ distilled water and $17.25 \mathrm{~mL} \mathrm{CH}_{3} \mathrm{CH}_{2} \mathrm{COOH}$ ) at a $\mathrm{pH}$ of 2.64. The liquid supernatant was then collected using a $0.45 \mathrm{~mm}$ pore size membranes after vibrating at $30 \pm 2 \mathrm{rpm}$ speed for 18 days at $23^{\circ} \mathrm{C}$ and analyzed by ICP-OES.

\section{Result and Discussion}

\subsection{Mix Proportion for Binder}

Table 4 shows that the OPC dosage has the greatest impact on the compressive strength of the samples followed by the ratio of gypsum. The weakest impact is the $\mathrm{NaOH}$ content.

Previous studies [14,15] reported that AAS enjoys higher shrinkage compared with OPC, especially when using blast furnace slag as the precursor materials [16]. As a result, a small amount of OPC was included in the binder in order to reduce the shrinkage of $\mathrm{CPB}$, because higher shrinkage will lead to the subsidence of the backfilling bodies $[17,18]$. On the other hand, several findings reported indicate the influence of OPC inclusion on the mechanical and rheological properties of the AAS samples. Nath et al. [19] found that both a general decreasing trend in slump and flowability of AAS mortar were influenced due to the inclusion of OPC, while the compressive strength increase. The addition of OPC may alter the alkali activated environment, because the hydration of OPC could generate portlandite which has been found to increase the early strength of the AAS samples [19]. However, excess amount of OPC may be harmful to the mechanical performance result from the unsatisfactory workability of the slurry.

Alkali activated solution ( $\mathrm{NaOH}$ solution in this study) has significant effect on both the compressive strength and structure of $\mathrm{C}-\mathrm{S}-\mathrm{H}$ in the process of alkali activated process. 
Generally speaking, $\mathrm{Si}^{4+}, \mathrm{Al}^{3+}, \mathrm{Ca}^{2+}$ and other minor ions begin to leach when raw materials come into contact with $\mathrm{NaOH}$ solution and the amount of leaching is dependent on the $\mathrm{OH}^{-}$concentration [20]. The surface hydrolysis of the raw material particles is also found to be relevant to the alkali solution concentration [21]. The compressive strength of alkali activated materials is reported to be sensitive to the degree of hydration reaction, which is strongly affected by the soluble ions of the alkali activated system [22]. On the other hand, the structure of $\mathrm{C}-\mathrm{S}-\mathrm{H}$ is also influenced by the type of the alkali activator. Compared with the $\mathrm{Na}_{2} \mathrm{SiO}_{3}$ solution activated slag, the $\mathrm{C}-(\mathrm{A})-\mathrm{S}-\mathrm{H}$ formed in the $\mathrm{NaOH}$ solution activated slag had a higher structural order and degree of cross-linking $[23,24]$. While higher dosage of $\mathrm{NaOH}$ could result in a decrease in the compressive strength of the alkali activated samples and similar results have been reported [25]. On the other hand, it should be highlighted here is that small dosage of OPC was used in the binder production. It has been reported that minor amounts of $\mathrm{NaOH}$ could improve the compressive strength of the low carbon cementitious materials, including fly ash, slag, OPC and gypsum [26]. While the high dosage of $\mathrm{NaOH}$ is not beneficial for the compressive strength of the binder samples [26], because $\mathrm{NaOH}$ lowers the total volume of hydration product, especially the volume of ettringite [27].

The compressive strength increase of the samples with gypsum is predominantly governed by the formation of ettringite $\left[\mathrm{Ca}_{6} \mathrm{Al}_{2}\left(\mathrm{SO}_{4}\right)_{3}(\mathrm{OH})_{12} \cdot 26 \mathrm{H}_{2} \mathrm{O}, \mathrm{AFt}\right.$, PDF\# 00-041-1451] [28], which results from the introduction of $\mathrm{SO}_{4}{ }^{2-}$ to the alkali activated environment along with gypsum. Also, it has been reported that the incorporation of gypsum leads to an increased reaction of $C_{3} A$ and $C_{4} A F$ in the OPC [29]. On the other hand, the clusters of finer ettringite crystals are found to be more effectively filled the pore spaces, leading to a denser matrix and higher compressive strength. However, higher dosage of gypsum decreases the compressive strength of samples. Ettringite possesses positive surface charge [30], electrostatic attraction can exist between the ettringite and slag particle which possesses negative surface charge. This could result in the bad workability of the binder slurry, then increase the porosity of the binder samples and decrease the compressive strength, which has been found to be dependent heavily on the porosity. Similar results have been reported in [31,32]. Based on the studies mentioned above, the optimal combination of binder is A1B1C1, the best $\mathrm{NaOH}$ content is $3 \mathrm{wt}$. $\%$, the optimal mass ratio of OPC is $7 \mathrm{wt}$. \%, and the best gypsum dosage is $4 \mathrm{wt}$. \%. Under these conditions, the final 28 days compressive strength of the binder is $29.55 \mathrm{MPa}$.

\subsection{Flowability of the CPB Slurry}

The flow spread and yield stress results of CPB mortar samples are illustrated in Table 5 and Figure $1 \mathrm{a}, \mathrm{b}$. It is obvious that the flow spread decreased with the increasing of solid content. Water can cover the surface of binder and tailings particles as a water film, playing a role in lubrication during the flow of CPB slurry. The increase of solid content can enhance the inter-particle contact [33], which will increase the force of friction between particles and decrease the lubrication effect of water and then hinder the flowability. On the other hand, contrary to the influence of the solid content, rising the binder dosage seems to be beneficial to the workability of $\mathrm{CPB}$ slurry. One of the critical factors affecting the workability of CPB slurry is the reaction of the binders, where dissolution of binders particles into solution and formation of reaction products in the binders particles surface and solution [12,34]. This will lead to the changing of the inter-particle force through the formation of new bonds and then the workability.

The yield stress of the CPB mortar samples are illustrated in Figure 1b. From the curves plotted, this rheological property gradually increased with the increase of the solid content rising. The flow spread also supported increasing in yield stress of the CPB slurry. A decrease of $\sim 67 \%$ flow spread was observed when solid content increased from $70 \%$ to $80 \%$ at the $12 \%$ binder dosage. The rising in particle aggregation in the $\mathrm{CPB}$ slurry resulted in the determination of hydrodynamic forces through the inter-particle forces $[6,35]$. Also, it can be seen that at the same solid content the yield stress decreased when increasing the binder dosage. Therefore, it can be concluded that the rheological properties of a CPB sample determine not only the solid content but also the binder dosage. 
Table 5. Flowability of the CPB slurry.

\begin{tabular}{ccccc}
\hline Binder Dosage (wt. \%) & Solid Content $^{\text {a }} \mathbf{( w t . ~ \% )}$ & Flow Spread $(\mathbf{c m})$ & Yield Stress (Pa) & WFT $(\boldsymbol{\mu m})$ \\
\hline \multirow{2}{*}{8} & 70 & 47.6 & 1.22 & 0.3311 \\
& 73 & 38.6 & 3.15 & 0.2757 \\
& 76 & 26.9 & 6.98 & 0.2121 \\
12 & 80 & 16.6 & 11.15 & 0.1600 \\
\hline & 70 & 39.6 & 0.82 & 0.4230 \\
& 73 & 31.1 & 2.18 & 0.3268 \\
& 76 & 22.1 & 6.01 & 0.2609 \\
& 80 & 12.9 & 9.03 & 0.1762 \\
\hline & 70 & 39.6 & 0.65 & 0.4897 \\
& 73 & 31.1 & 1.39 & 0.3690 \\
& 76 & 22.1 & 4.19 & 0.2972 \\
& 80 & 12.9 & 6.71 & 0.1932 \\
\hline & 70 & 42.6 & 0.56 & 0.5234 \\
& 73 & 37.6 & 1.04 & 0.4523 \\
& 76 & 26.9 & 2.98 & 0.3031 \\
\hline
\end{tabular}

${ }^{\mathrm{a}}$ solid includes binder, $\mathrm{MT}$ and $\mathrm{NaOH}$.

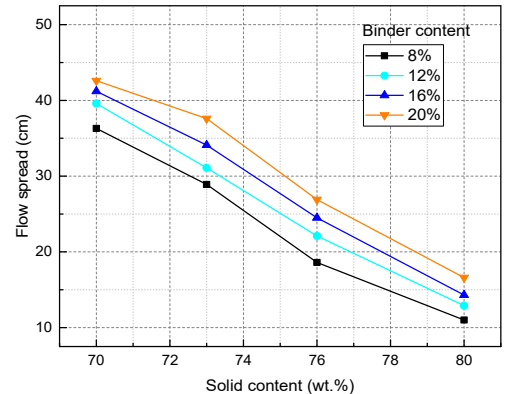

(a)

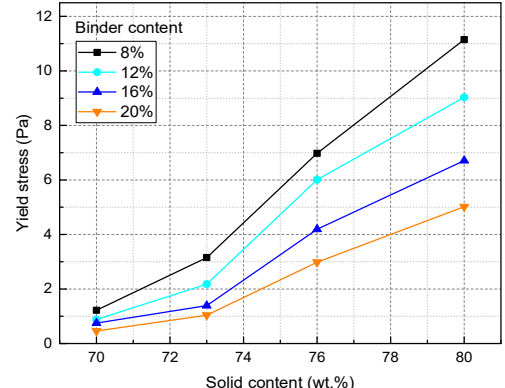

(b)

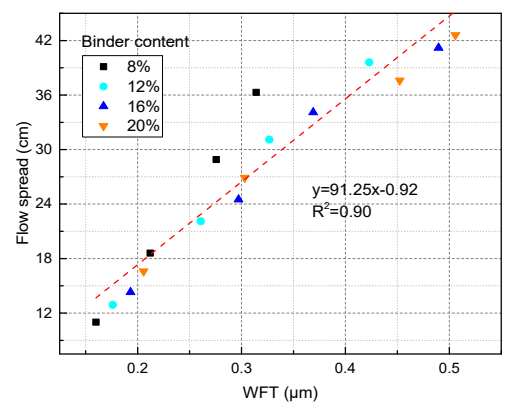

(c)

Figure 1. Flowability of CPB slurry. (a) Relationship between solid content and flow spread, (b) Relationship between solid content and yield stress, (c) Relationship between WFT and flow spread.

The water film thickness (WFT) of CPB samples are tabulated in Table 5. To better understand how the WFT is related to flow spread, the WFT is plotted versus flow spread in Figure 1c. Generally, from Figure 1c, it can be seen that the flow spread increased with the WFT at almost a constant rate. Regression analysis has been used to study the effect of WFT, deriving a best-fit curve for the flow spread-WFT relation. The straight-line form, coupled with the high $\mathrm{R}^{2}$ value of 0.9 , reveals that the flow spread-WFT relation is generally linear. As has been shown by Zhang et al. [36,37], there are two 
types of water in cemented paste: filling water and excess water. The filling water can fill into the voids between solid particles, which does not contribute to the workability of the slurry. While the excess water can form a water film on the surface of the solid particles and enhance the flowability of the slurry. As the particles in the CPB slurry could not easily roll over each other, large WFT can provide lubrication to the binder and aggregate particles and then the slurry would become quite flowable [37]. While when the WFT is small, particles are not sufficiently lubricated and the friction force between inter-particles could hinder the hydrodynamic movement of the slurry, contributing to the decrease the flow spread.

\subsection{Strength Properties}

Strength properties of the CPB samples are studied in this section in order to reach a predictive model for the compressive strength of CPB samples. Table 6 shows the compressive strength of $\mathrm{CPB}$ samples with various binder dosage, solid content and curing periods through experimental studies.

Table 6. Compressive strength of CPB samples.

\begin{tabular}{cccccc}
\hline \multirow{2}{*}{ Binder Dosage (wt. \%) } & \multirow{2}{*}{ Solid Content (wt. \%) } & \multicolumn{4}{c}{ Compressive (MPa) } \\
\cline { 3 - 5 } & & 3 Days & 7 Days & 14 Days & 28 Days \\
\hline \multirow{2}{*}{$20 \%$} & 70 & 0.69 & 1.12 & 2.26 & 2.72 \\
& 73 & 0.94 & 1.55 & 2.52 & 2.85 \\
& 76 & 1.15 & 1.70 & 2.66 & 3.40 \\
$16 \%$ & 80 & 1.68 & 2.64 & 3.77 & 4.87 \\
\hline \multirow{2}{*}{$16 \%$} & 70 & 0.51 & 0.69 & 1.78 & 2.13 \\
& 73 & 0.65 & 0.96 & 1.91 & 2.36 \\
& 76 & 0.89 & 1.48 & 2.52 & 3.03 \\
& 80 & 1.03 & 1.66 & 2.87 & 3.85 \\
\hline \multirow{2}{*}{$8 \%$} & 70 & 0.64 & 0.85 & 0.92 & 1.15 \\
& 73 & 0.84 & 0.91 & 1.08 & 1.26 \\
& 76 & 0.91 & 1.11 & 1.27 & 1.66 \\
& 80 & 0.96 & 1.23 & 1.76 & 2.20 \\
\hline & 70 & 0.26 & 0.44 & 0.60 & 0.90 \\
& 73 & 0.46 & 0.61 & 0.78 & 1.17 \\
& 76 & 0.59 & 0.93 & 0.98 & 1.26 \\
& 80 & 0.89 & 1.02 & 1.23 & 1.61 \\
\hline
\end{tabular}

\subsubsection{Multivariate Analysis}

The compressive strength of CPB samples is closely related to a single factor, but generally speaking, the growth of its compressive strength is determined by the combined action of all influencing factors. The curing period of the $\mathrm{CPB}$ samples was set as an invariant to study the compressive strength characteristics of $\mathrm{CPB}$ samples under the combining effect of solid content and binder dosage. Since the experimental scheme selected in the test process cannot completely cover all the intensity data needed in the practical application process, the estimation based on the previous test data and experience lacks objectivity. In order to predict more accurately, MATLAB software (2015b, MathWorks, Natick, MA, USA) was used to conduct fitting analysis on the test results of different proportion schemes of slag cementing materials cementing the whole tailings. By using the method of fitting analysis, strength data are analyzed to determine the fitting equation of strength at different ages, which can be used to predict the compressive strength of CPB samples. The compressive strength at different curing period is a dependent variable, set as $y$, two independent variables are binder dosage and solid content, set as $x_{1}$ and $x_{2}$, respectively. The fitting equation and correlation coefficient $R_{2}$ values are shown in Table 7 .

It can be seen from Table 7 that the correlation coefficient $R^{2}$ values of the fitted curves at 7 , 14 and 28 days are all greater than 0.95 , indicating that the fitted curves at these three ages are of high accuracy and can basically reflect the quantitative relationship between the compressive strength of 
CPB samples and the binder dosage and solid content. Compared with the $\mathrm{R}^{2}$ values at 7, 14 and 28 days, the correlation coefficient $R^{2}$ value of the fitting curve at 3 days age is about 0.90 , and its accuracy is relatively low.

Based on the formula listed in Table 7, the compressive strength value and the error value at different binder dosage and solid content are shown in Table 8. From Table 8, it can be seen that the error values between the predicted and experimental compressive strength of CPB samples maintained at approximately $0.1 \mathrm{MPa}$. While this error values for the $\mathrm{CPB}$ samples cured for 28 days is larger, $\sim 0.2 \mathrm{MPa}$. Anyway, the overall predicted values are close to the experimental values, that means the secondary multivariate fitting equation can used to predict the compressive strength values of $\mathrm{CPB}$ samples at different solid content and binder dosage with various curing periods.

Table 7. Results of fitting analysis.

\begin{tabular}{cccc}
\hline Curing Period (d) & Fitting Equation & Standard Errors & Correlation Coefficient $\left(\mathbf{R}^{2}\right)$ \\
\hline \multirow{2}{*}{3} & $y_{1}=27.5665-19.2973 x_{1}{ }^{2}+$ & & \\
& $50.6791 x_{2}^{2}-24.0004 x_{1}-$ & 0.1368 & 0.9016 \\
& $75.1738 x_{2}+45.9925 x_{1} x_{2}$ & & \\
& $y_{2}=60.3656-27.5251 x_{1}{ }^{2}+$ & & 0.9578 \\
7 & $105.9263 x_{2}{ }^{2}-53.7166 x_{1}-$ & 0.1428 & \\
& $160.9699 x_{2}+94.3906 x_{1} x_{2}$ & & 0.9614 \\
& $y_{3}=100.3304-112.6050 x_{1}{ }^{2}+$ & & \\
14 & $192.4251 x_{2}^{2}+5.1676 x_{1}-$ & 0.1807 & \\
& $282.8351 x_{2}+64.1722 x_{1} x_{2}$ & & 0.9549 \\
& $y_{4}=151.7099-129.9277 x_{1}{ }^{2}+$ & & \\
28 & $280.8141 x_{2}^{2}-7.3326 x_{1}-$ & 0.2525 & \\
& $418.3366 x_{2}+119.5032 x_{1} x_{2}$ & & \\
\hline
\end{tabular}

Table 8. The predicted value and deviation of AAS-CPB strength.

\begin{tabular}{|c|c|c|c|c|c|c|c|c|c|}
\hline $\begin{array}{c}\text { Binder Dosage } \\
\text { (Wt. \%) }\end{array}$ & $\begin{array}{l}\text { Solid Content } \\
\text { (Wt. \%) }\end{array}$ & \multicolumn{2}{|c|}{3 Days } & \multicolumn{2}{|c|}{7 Days } & \multicolumn{2}{|c|}{14 Days } & \multicolumn{2}{|c|}{28 Days } \\
\hline \multirow{3}{*}{$20 \%$} & $73 \%$ & 0.884 & 0.056 & 1.483 & 0.067 & 2.369 & 0.150 & 2.826 & 0.024 \\
\hline & $76 \%$ & 1.239 & 0.089 & 1.896 & 0.196 & 2.867 & 0.207 & 3.624 & 0.224 \\
\hline & $80 \%$ & 1.854 & 0.174 & 2.813 & 0.173 & 4.103 & 0.333 & 5.408 & 0.538 \\
\hline \multirow{3}{*}{$16 \%$} & $73 \%$ & 0.757 & 0.105 & 0.873 & 0.087 & 1.945 & 0.035 & 2.345 & 0.014 \\
\hline & $76 \%$ & 0.996 & 0.106 & 1.450 & 0.029 & 2.382 & 0.137 & 2.945 & 0.085 \\
\hline & $80 \%$ & 1.158 & 0.128 & 1.851 & 0.191 & 3.204 & 0.334 & 4.331 & 0.481 \\
\hline \multirow{2}{*}{$12 \%$} & $70 \%$ & 0.613 & 0.027 & 0.705 & 0.144 & 1.135 & 0.215 & 1.383 & 0.233 \\
\hline & $73 \%$ & 0.792 & 0.048 & 0.874 & 0.036 & 1.146 & 0.066 & 1.427 & 0.167 \\
\hline \multirow{3}{*}{$8 \%$} & $73 \%$ & 0.461 & 0.001 & 0.549 & 0.061 & 0.579 & 0.201 & 0.961 & 0.209 \\
\hline & $76 \%$ & 0.609 & 0.019 & 0.738 & 0.191 & 0.788 & 0.191 & 1.022 & 0.238 \\
\hline & $80 \%$ & 0.948 & 0.058 & 1.186 & 0.166 & 1.538 & 0.308 & 2.089 & 0.479 \\
\hline
\end{tabular}

\subsubsection{Sensitivity Analysis}

Based on the above analysis, all factors including binder dosage, solid content and curing period have great influence on the compressive strength of $\mathrm{CPB}$ samples, however, the sensitivity degree is different. Then the grey correlation analysis method is used to obtain the corresponding correlation coefficient, aiming at studying the degree of influence of the above three factors on the compressive strength of $\mathrm{CPB}$ samples and judging the primary and secondary influencing factors. Grey correlation analysis reflects the degree of correlation between two variables in the development process through the degree of correlation degree. The compressive strength of the CPB samples is set as the mother factor, 
solid content, binder dosage and curing period are taken as sub-factors to establish the corresponding grey correlation model. The correlation degree between three factors and the compressive strength is obtained respectively.

According to the orthogonal test design principle of $\mathrm{L}_{16}\left(4^{3}\right), 16$ groups of test data in Table 9 are selected for grey correlation analysis. In order to make the data comparable, ensure the accuracy of the grey correlation analysis model and the accuracy of the system analysis results, the original data need to be un-dimensioned processed. In this paper, the initial value transformation method is selected for dimensionless data processing, that is:

$$
\begin{gathered}
X_{\mathrm{i}}=\left(x_{\mathrm{i}}(1), x_{\mathrm{i}}(2), \ldots, x_{\mathrm{i}}(\mathrm{n})\right) \\
X_{\mathrm{i}}^{0}=X_{\mathrm{i}}(\mathrm{k}) / x_{\mathrm{i}}(1)=\left(\left(x_{\mathrm{i}}^{0}(\mathrm{a}), x_{\mathrm{i}}^{0}(2), \ldots, x_{\mathrm{i}}^{0}(\mathrm{n})\right)\right.
\end{gathered}
$$

where $X_{i}$ is behavior sequence of $i$, and $X^{0}{ }_{i}$ is the behavior sequence after initialization processing; The correlation coefficient $\left(\zeta_{\mathrm{oi}}(k)\right)$ between the sub-factor and mother factor can be express as:

$$
\zeta_{\mathrm{oi}}(k)=\frac{m+\rho M}{\Delta_{i}(k)+\rho M}
$$

where $\rho$ is the resolution coefficient extending from 0 to 1 , and 0.5 is used in this paper.

$$
\begin{gathered}
M=\min \min \Delta_{\mathrm{i}}(k) \\
M=\max \max \Delta_{\mathrm{i}}(k) \\
\Delta_{\mathrm{i}}(k)=\left|x_{1}^{0}(k)-x_{i}^{0}(k)\right|
\end{gathered}
$$

where $k=(1,2,3, \ldots \mathrm{n})$ is number of levels, $I=(1,2,3, \ldots \mathrm{m})$ is the number of factors series, and $M$ and $m$ are the maximum and minimum in $\Delta_{\mathrm{i}}(k)$, respectively. Then the correlation coefficient $\left(\zeta_{\mathrm{oi}}(k)\right)$ can be expressed as:

$$
\zeta_{\mathrm{i}}(k)=\frac{1}{n} \sum_{k=1}^{n} \zeta_{o i}(\mathrm{k})
$$

The compressive strength of the 16 groups of $\mathrm{CPB}$ samples are taken as the reference sequence, that is $I=0 . I=1,2,3$ represent binder dosage, curing period and solid content. The calculation results using the matrix calculation method in linear algebra are listed in Table 9. It can be seen from Table 9 that the influence degree of binder content, curing period and solid content on the compressive strength of the $\mathrm{CPB}$ samples is different, and the corresponding correlation coefficient is $0.759,0.737$ and 0.826 respectively, indicating that these factors have important influences on the development of $\mathrm{CPB}$ strength.

Meanwhile, within the scope studied in this paper, the compressive strength of the CPB samples is the most sensitive to solid content, which enjoys the larger correlation coefficient value. While the curing period is the least sensitive factor. At the same binder dosage, higher solid content means less water in the slurry, resulting in a higher $\mathrm{pH}$ environment, which will enhance the hydration degree of the slag and generate higher amount of hydration product. In general, higher hydration product could enhance the compressive strength of the CPB samples. 
Table 9. Calculation results of correlation degree.

\begin{tabular}{cccc}
\hline No. & $\zeta_{\mathbf{0 1}}(\boldsymbol{k})$ & $\zeta_{\mathbf{0 2}}(\boldsymbol{k})$ & $\boldsymbol{\zeta}_{\mathbf{0 3}}(\boldsymbol{k})$ \\
\hline 1 & 1.000 & 1.000 & 1.000 \\
2 & 0.763 & 0.979 & 0.769 \\
3 & 0.584 & 0.832 & 0.592 \\
4 & 0.399 & 0.638 & 0.404 \\
5 & 0.962 & 0.958 & 0.949 \\
6 & 0.923 & 0.751 & 1.000 \\
7 & 0.535 & 0.888 & 0.571 \\
8 & 0.519 & 0.448 & 0.548 \\
9 & 0.831 & 0.926 & 0.945 \\
10 & 0.758 & 0.879 & 0.863 \\
11 & 0.828 & 0.546 & 0.923 \\
12 & 0.752 & 0.348 & 0.837 \\
13 & 0.819 & 0.933 & 0.965 \\
14 & 0.809 & 0.803 & 0.939 \\
15 & 0.846 & 0.532 & 0.979 \\
16 & 0.816 & 0.333 & 0.930 \\
Correlation degree & 0.759 & 0.737 & 0.826 \\
\hline
\end{tabular}

\subsection{Leaching Properties}

From Table 2 in the Section 2.1, only the $\mathrm{Pb}$ and $\mathrm{Cd}$ concentration in the leachate exceeds the threshold according to GB 16889-2008, so in this study, only the leaching properties of $\mathrm{Pb}$ and $\mathrm{Cd}$ was explored. The effect of different binder content $(12 \%, 16 \%$ and $20 \%)$ and curing period $(3 \mathrm{~d}, 7 \mathrm{~d}, 28 \mathrm{~d})$ on $\mathrm{Pb}$ and $\mathrm{Cd}$ concentration in the leachate is displayed in Figure 2.
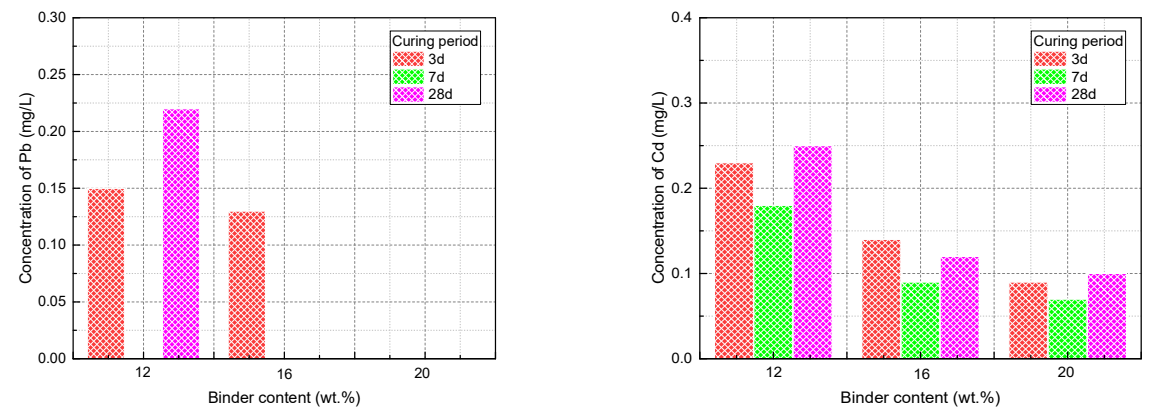

Figure 2. Leaching concentration of $\mathrm{Cd}$ and $\mathrm{Pb}$ with different binder content and curing period.

According to the GB16889-2008, the limit values of Cd and Pd concentration are 0.15 and $0.25 \mathrm{mg} / \mathrm{L}$. Obviously, the leaching concentration of $\mathrm{Pb}$ was below the threshold with all the binder concentration and curing period. While for $\mathrm{Cd}$, in general, the leaching concentration decreased with the increasing of binder content. When using $12 \%$ binder content, the leaching concentration of $\mathrm{Cd}$ was $0.23,0.18$ and $0.25 \mathrm{mg} / \mathrm{L}$ at 3, 7 and 28 days curing respectively, which exceeded the leaching threshold. Increasing the binder content to $16 \%$ and $20 \%$ contributed to the reduction of leaching concentration of $\mathrm{Cd}$ to below the threshold. This result can be explained as follows.

Firstly, in the process of alkali activation process, $\mathrm{Si}$ and $\mathrm{Al}$ ions can leaching from the slag and polycondensation reaction will happen under the alkali solution, resulting into $\left(\mathrm{SiO}(\mathrm{OH})_{3}\right)^{-}$, $\left(\mathrm{SiO}_{2}(\mathrm{OH})_{2}\right)^{2-},\left(\mathrm{SiO}_{3}(\mathrm{OH})\right)^{3-}$ and $\left(\mathrm{Al}(\mathrm{OH})_{4}\right)^{-}$and then form amorphous three-dimensional network structure [38-40]. During this process, the heavy metal ions, such as $\mathrm{Pb}, \mathrm{Cd}, \mathrm{Zn}$ and $\mathrm{Cr}$, can be encapsulated into the structure resulting from the coating effect of amorphous gels [38]. On the other hand, the gels generated from the alkali activation, such as $\mathrm{C}-\mathrm{S}-\mathrm{H}, \mathrm{C}-\mathrm{A}-\mathrm{S}-\mathrm{H}$ and $\mathrm{N}-\mathrm{A}-\mathrm{S}-\mathrm{H}$, have a poorly ordered and layered structure. These gels possess higher specific surface area and adsorption capacity and could adsorb heavy metals onto their surface [41]. Gineys et al. [42] summarized the potential positions occupied by heavy metals in the structure of $\mathrm{C}-\mathrm{S}-\mathrm{H}$. Many studies found that 
the adsorption phenomenon of heavy metals onto the surface C-S-H. The alkali activated materials were also prepared into adsorbent for removal heavy metals from aqueous solution [43-53]. Then the adsorption of heavy metal onto the surface of the alkali activated gels could be regards as one of the mechanisms of the immobilization. As a result, when using higher binder content in the present study, more gels can generate, enhancing the encapsulation and adsorption effect. Secondly, ettringite $\left(\mathrm{AFt}, 3 \mathrm{CaO} \cdot \mathrm{Al}_{2} \mathrm{O}_{3} \cdot 3 \mathrm{CaSO}_{4} \cdot 32 \mathrm{H}_{2} \mathrm{O}\right)$ is one of the hydration products in the cement system which has a needle-like structure and also be found in the alkali activated process [54], which has a needle-like structure. It has been reported that the sulfates in the channels of AFt are tend to be replaced by the oxyanions with similar structure, such as $\mathrm{CrO}_{4}{ }^{2-}, \mathrm{SeO}_{4}{ }^{2-}, \mathrm{VO}_{4}{ }^{2-}$ and $\mathrm{PbO}_{4}{ }^{4-}$ [55-58]. Compared with $\mathrm{AFt}$, monosulfate $\left(\mathrm{AFm}, 3 \mathrm{CaO} \cdot \mathrm{Al}_{2} \mathrm{O}_{3} \cdot \mathrm{CaSO}_{4} \cdot 12 \mathrm{H}_{2} \mathrm{O}\right)$, a conversion product of $\mathrm{AFt}$ after one day hydration $[13,59]$ seems to be more seem to possess better immobilization effects on oxyanions due to the layered structure $[54,60,61]$. Furthermore, the structure of alkali activated materials could be expressed as $\mathrm{M}_{\mathrm{n}}\left[-(\mathrm{Si}-\mathrm{O})_{\mathrm{z}}-\mathrm{Al}-\mathrm{O}\right] \mathrm{n} \cdot \mathrm{mH}_{2} \mathrm{O}$, where $\mathrm{M}$ stands for an alkali metal cation, such as $\mathrm{Na}, \mathrm{K}$ and $\mathrm{Li}$ [62]. The heavy metal ions $\left(\mathrm{Zn}^{2+}, \mathrm{Cu}^{2+}, \mathrm{Cd}^{2+}\right.$ and $\left.\mathrm{Cr}^{3+}\right)$ have also been reported to be a substitute of the alkali metal cation [63-65], which is deemed to be one of the immobilization mechanisms.

Another phenomenon was noticed was the increased $\mathrm{Cd}$ concentration in the leachate after curing for $28 \mathrm{~d}$, similar results has been reported in previous studies $[66,67]$. In the process of alkali activated process, the $\mathrm{pH}$ of the slurry will decrease due to the hydration of BFS, which will increase the mobility of $\mathrm{Cd}$ and then the leaching concentration will increase.

\section{Conclusions}

In this paper, a new low-carbon binder, alkali activated slag (AAS), has been prepared. From orthogonal tests, the influences of $\mathrm{NaOH}$ content, $\mathrm{OPC}$ dosage and ratio of gypsum on the 28 days compressive strength of binder samples were studied. Flow spread and yield stress tests were used to explore the rheological properties of the $\mathrm{CPB}$ slurry. A predictive model of the compressive strength of $\mathrm{CPB}$ samples was reached through multivariate analysis. TCLP tests were used to explore the leaching properties of the toxic elements from the $\mathrm{CPB}$ samples. Based on the results of the experimental tests performed, the following conclusions can be drawn:

(1) Based on the orthogonal tests, the optimal combination of binder was A1B1C1, the best $\mathrm{NaOH}$ content was $3 \mathrm{wt}$. \%, the optimal mass ratio of OPC was $7 \mathrm{wt}$. \%, and the best gypsum dosage was 4 wt. \%. Under these conditions, the final 28 days compressive strength of the binder was $29.55 \mathrm{MPa}$;

(2) Increasing the solid content could increase the yield stress of the CPB slurry and then decrease the flow ability. While higher binder dosage content decreased the yield stress of the slurry and increased the flow ability;

(3) The compressive strength predictive model was used through the strength properties analysis. The correlation coefficient $R^{2}$ values of the fitting equations were higher than 0.9 , indicating a good predictive efficiency. Sensitivity analysis showed that the solid content is the most important influences on the development of the CPB strength with a correlation coefficient of 0.826 ;

(4) The leaching concentration of $\mathrm{Pb}$ was below the threshold using AAS as an alternative binder for cemented paste backfill. The leaching concentration of $\mathrm{Cd}$ decreased with tFhe increasing of binder content. Increasing the binder content to $16 \%$ and $20 \%$ reduced the leaching concentration of $\mathrm{Cd}$ to below the threshold.

Supplementary Materials: The following are available online at http://www.mdpi.com/2075-163X/9/11/707/s1, Figure S1: Particle size distribution of tailings, Figure S2: XRD results, Figure S3: Microstructure after curing for 60 days, Table S1: Main components oftailings/wt. \%.

Author Contributions: All authors conceived and designed the experiments; J.X. and Y.Z. performed the experiments and analyzed the results; Y.Z. wrote the original draft; J.Q., X.S., H.L., and Z.G. reviewed and edited the manuscript. 
Funding: The authors gratefully acknowledge the financial support from National Science and Technology Support Plan, 2018YFC0604604, National Science Foundation, 51774066 and Research and development project, Liaoning, 2019JH2/10300051.

Conflicts of Interest: The authors declare no conflict of interest.

\section{References}

1. Luukkonen, T.; Abdollahnejad, Z.; Yliniemi, J.; Kinnunen, P.; Illikainen, M. One-part alkali-activated materials: A review. Cem. Concr. Res. 2018, 103, 21-34. [CrossRef]

2. Zhu, W.; Teoh, P.J.; Liu, Y.; Chen, Z.; Yang, E.-H. Strategic utilization of municipal solid waste incineration bottom ash for the synthesis of lightweight aerated alkali-activated materials. J. Clean. Prod. 2019, 235, 603-612. [CrossRef]

3. Zhu, W.; Chen, X.; Zhao, A.; Struble, L.J.; Yang, E.-H. Synthesis of high strength binders from alkali activation of glass materials from municipal solid waste incineration bottom ash. J. Clean. Prod. 2019, 212, 261-269. [CrossRef]

4. Zhang, X.; Han, Y.; Sun, Y.; Li, Y. Innovative utilization of refractory iron ore via suspension magnetization roasting: A pilot-scale study. Powder Technol. 2019, 352, 16-24. [CrossRef]

5. Jiang, H.; Qi, Z.; Yilmaz, E.; Han, J.; Qiu, J.; Dong, C. Effectiveness of alkali-activated slag as alternative binder on workability and early age compressive strength of cemented paste backfills. Constr. Build. Mater. 2019, 218, 689-700. [CrossRef]

6. Ishwarya, G.; Singh, B.; Deshwal, S.; Bhattacharyya, S.K. Effect of sodium carbonate/sodium silicate activator on the rheology, geopolymerization and strength of fly ash/slag geopolymer pastes. Cem. Concr. Compos. 2019, 97, 226-238. [CrossRef]

7. Cihangir, F.; Ercikdi, B.; Kesimal, A.; Turan, A.; Deveci, H. Utilisation of alkali-activated blast furnace slag in paste backfill of high-sulphide mill tailings: Effect of binder type and dosage. Miner. Eng. 2012, 30, $33-43$. [CrossRef]

8. Zhao, Y.; Soltani, A.; Taheri, A.; Karakus, M.; Deng, A. Application of Slag-Cement and Fly Ash for Strength Development in Cemented Paste Backfills. Minerals 2019, 9, 22. [CrossRef]

9. GB 16889-2008. Domestic Waste Landfill Control Standards; Chinese Academy of Environmental Sciences: Beijing, China, 2008.

10. ASTM D2166/D2166M-16. Standard Test Method for Unconfined Compressive Strength of Cohesive Soil; ASTM International: West Conshohocken, PA, USA, 2016.

11. ASTM C1437-15. Standard Test Method for Flow of Hydraulic Cement Mortar; ASTM International: West Conshohocken, PA, USA, 2015.

12. Kashani, A.; Provis, J.L.; Qiao, G.G.; van Deventer, J.S.J. The interrelationship between surface chemistry and rheology in alkali activated slag paste. Constr. Build. Mater. 2014, 65, 583-591. [CrossRef]

13. Guo, B.; Liu, B.; Yang, J.; Zhang, S. The mechanisms of heavy metal immobilization by cementitious material treatments and thermal treatments: A review. J. Environ. Manag. 2017, 193, 410-422. [CrossRef]

14. Tu, W.; Zhu, Y.; Fang, G.; Wang, X.; Zhang, M. Internal curing of alkali-activated fly ash-slag pastes using superabsorbent polymer. Cem. Concr. Res. 2019, 116, 179-190. [CrossRef]

15. Thomas, J.J.; Allen, A.J.; Jennings, H.M. Density and water content of nanoscale solid C-S-H formed in alkali-activated slag (AAS) paste and implications for chemical shrinkage. Cem. Concr. Res. 2012, 42, 377-383. [CrossRef]

16. Lee, N.K.; Jang, J.G.; Lee, H.K. Shrinkage characteristics of alkali-activated fly ash/slag paste and mortar at early ages. Cem. Concr. Compos. 2014, 53, 239-248. [CrossRef]

17. Qiu, J.; Yang, L.; Sun, X.; Xing, J.; Li, S. Strength Characteristics and Failure Mechanism of Cemented Super-Fine Unclassified Tailings Backfill. Minerals 2017, 7, 58. [CrossRef]

18. Yang, L.; Qiu, J.; Jiang, H.; Hu, S.; Li, H.; Li, S. Use of Cemented Super-Fine Unclassified Tailings Backfill for Control of Subsidence. Minerals 2017, 7, 216. [CrossRef]

19. Nath, P.; Sarker, P.K. Use of OPC to improve setting and early strength properties of low calcium fly ash geopolymer concrete cured at room temperature. Cem. Concr. Compos. 2015, 55, 205-214. [CrossRef]

20. Görhan, G.; Kürklü, G. The influence of the $\mathrm{NaOH}$ solution on the properties of the fly ash-based geopolymer mortar cured at different temperatures. Compos. Part B Eng. 2014, 58, 371-377. [CrossRef] 
21. Rattanasak, U.; Chindaprasirt, P. Influence of $\mathrm{NaOH}$ solution on the synthesis of fly ash geopolymer. Miner. Eng. 2009, 22, 1073-1078. [CrossRef]

22. Phoo-ngernkham, T.; Maegawa, A.; Mishima, N.; Hatanaka, S.; Chindaprasirt, P. Effects of sodium hydroxide and sodium silicate solutions on compressive and shear bond strengths of FA-GBFS geopolymer. Constr. Build. Mater. 2015, 91, 1-8. [CrossRef]

23. Puertas, F.; Fernández-Jiménez, A.; Blanco-Varela, M.T. Pore solution in alkali-activated slag cement pastes. Relation to the composition and structure of calcium silicate hydrate. Cem. Concr. Res. 2004, 34, 139-148. [CrossRef]

24. Zuo, Y.; Nedeljković, M.; Ye, G. Pore solution composition of alkali-activated slag/fly ash pastes. Cem. Concr. Res. 2019, 115, 230-250. [CrossRef]

25. Ahmari, S.; Zhang, L. Production of eco-friendly bricks from copper mine tailings through geopolymerization. Constr. Build. Mater. 2012, 29, 323-331. [CrossRef]

26. Wu, M.; Zhang, Y.; Jia, Y.; She, W.; Liu, G.; Wu, Z.; Sun, W. Influence of sodium hydroxide on the performance and hydration of lime-based low carbon cementitious materials. Constr. Build. Mater. 2019, 200, 604-615. [CrossRef]

27. Mota, B.; Matschei, T.; Scrivener, K. Impact of $\mathrm{NaOH}$ and $\mathrm{Na} 2 \mathrm{SO} 4$ on the kinetics and microstructural development of white cement hydration. Cem. Concr. Res. 2018, 108, 172-185. [CrossRef]

28. Jeong, Y.; Oh, J.E.; Jun, Y.; Park, J.; Ha, J.-h.; Sohn, S.G. Influence of four additional activators on hydrated-lime $\left[\mathrm{Ca}(\mathrm{OH})_{2}\right]$ activated ground granulated blast-furnace slag. Cem. Concr. Compos. 2016, 65, 1-10. [CrossRef]

29. de la Grée, G.C.H.D.; Yu, Q.L.; Brouwers, H.J.H. Assessing the effect of $\mathrm{CaSO}_{4}$ content on the hydration kinetics, microstructure and mechanical properties of cements containing sugars. Constr. Build. Mater. 2017, 143, 48-60. [CrossRef]

30. Tian, H.; Kong, X.; Su, T.; Wang, D. Comparative study of two PCE superplasticizers with varied charge density in Portland cement and sulfoaluminate cement systems. Cem. Concr. Res. 2019, 115, 43-58. [CrossRef]

31. Park, H.; Jeong, Y.; Jun, Y.; Jeong, J.-H.; Oh, J.E. Strength enhancement and pore-size refinement in clinker-free $\mathrm{CaO}-$ activated GGBFS systems through substitution with gypsum. Cem. Concr. Compos. 2016, 68, 57-65. [CrossRef]

32. Neto, A.A.M.; Cincotto, M.A.; Repette, W. Mechanical properties, drying and autogenous shrinkage of blast furnace slag activated with hydrated lime and gypsum. Cem. Concr. Compos. 2010, 32, 312-318. [CrossRef]

33. Simon, D.; Grabinsky, M. Apparent yield stress measurement in cemented paste backfill. Int. J. Min. Reclam. Environ. 2013, 27, 231-256. [CrossRef]

34. Steins, P.; Poulesquen, A.; Diat, O.; Frizon, F. Structural Evolution during geopolymerization from an early age to consolidated material. Langmuir 2012, 28, 8502-8510. [CrossRef] [PubMed]

35. Yammine, J.; Chaouche, M.; Guerinet, M.; Moranville, M.; Roussel, N. From ordinary rhelogy concrete to self compacting concrete: A transition between frictional and hydrodynamic interactions. Cem. Concr. Res. 2008, 38, 890-896. [CrossRef]

36. Zhang, C.; Wang, A.; Tang, M.; Liu, X. The filling role of pozzolanic material. Cem. Concr. Res. 1996, 26, 943-947. [CrossRef]

37. Fung, W.W.S.; Kwan, A.K.H. Role of water film thickness in rheology of CSF mortar. Cem. Concr. Compos. 2010, 32, 255-264. [CrossRef]

38. Ji, Z.; Pei, Y. Bibliographic and visualized analysis of geopolymer research and its application in heavy metal immobilization: A review. J. Environ. Manag. 2019, 231, 256-267. [CrossRef]

39. Xing, J.; Zhao, Y.; Qiu, J.; Sun, X. Microstructural and Mechanical Properties of Alkali Activated Materials from Two Types of Blast Furnace Slags. Materials (Basel) 2019, 12, 2089. [CrossRef]

40. Qiu, J.; Zhao, Y.; Xing, J.; Sun, X. Fly Ash/Blast Furnace Slag-Based Geopolymer as a Potential Binder for Mine Backfilling: Effect of Binder Type and Activator Concentration. Adv. Mater. Sci. Eng. 2019, 2019, 1-12. [CrossRef]

41. Li, Y.; Min, X.; Ke, Y.; Fei, J.; Liu, D.; Tang, C. Immobilization potential and immobilization mechanism of arsenic in cemented paste backfill. Miner. Eng. 2019, 138, 101-107. [CrossRef]

42. Gineys, N.; Aouad, G.; Damidot, D. Managing trace elements in Portland cement-Part I: Interactions between cement paste and heavy metals added during mixing as soluble salts. Cem. Concr. Compos. 2010, 32, 563-570. [CrossRef] 
43. Qiu, J.; Zhao, Y.; Xing, J.; Sun, X. Fly ash-based geopolymer as a potential adsorbent for Cr(VI) removal. DWT 2017, 70, 201-209. [CrossRef]

44. Rasaki, S.A.; Bingxue, Z.; Guarecuco, R.; Thomas, T.; Minghui, Y. Geopolymer for use in heavy metals adsorption, and advanced oxidative processes: A critical review. J. Clean. Prod. 2019, 213, 42-58. [CrossRef]

45. Bumanis, G.; Novais, R.M.; Carvalheiras, J.; Bajare, D.; Labrincha, J.A. Metals removal from aqueous solutions by tailored porous waste-based granulated alkali-activated materials. Appl. Clay Sci. 2019, 179, 105147. [CrossRef]

46. Shao, N.; Tang, S.; Liu, Z.; Li, L.; Yan, F.; Liu, F.; Li, S.; Zhang, Z. Hierarchically Structured Calcium Silicate Hydrate-Based Nanocomposites Derived from Steel Slag for Highly Efficient Heavy Metal Removal from Wastewater. ACS Sustain. Chem. Eng. 2018, 6, 14926-14935. [CrossRef]

47. Kuwahara, Y.; Tamagawa, S.; Fujitani, T.; Yamashita, H. A novel conversion process for waste slag: synthesis of calcium silicate hydrate from blast furnace slag and its application as a versatile adsorbent for water purification. J. Mater. Chem. A 2013, 1, 7199. [CrossRef]

48. Wu, J.; Zhu, Y.-J.; Chen, F. Ultrathin calcium silicate hydrate nanosheets with large specific surface areas: synthesis, crystallization, layered self-assembly and applications as excellent adsorbents for drug, protein, and metal ions. Small 2013, 9, 2911-2925. [CrossRef]

49. Siyal, A.A.; Shamsuddin, M.R.; Rabat, N.E.; Zulfiqar, M.; Man, Z.; Low, A. Fly ash based geopolymer for the adsorption of anionic surfactant from aqueous solution. J. Clean. Prod. 2019, 229, 232-243. [CrossRef]

50. Chen, X.; Guo, Y.; Ding, S.; Zhang, H.; Xia, F.; Wang, J.; Zhou, M. Utilization of red mud in geopolymer-based pervious concrete with function of adsorption of heavy metal ions. J. Clean. Prod. 2019, 207, 789-800. [CrossRef]

51. Demir, F; Derun, E.M. Modelling and optimization of gold mine tailings based geopolymer by using response surface method and its application in $\mathrm{Pb}^{2+}$ removal. J. Clean. Prod. 2019, 237, 117766. [CrossRef]

52. Ferone, C.; Capasso, I.; Bonati, A.; Roviello, G.; Montagnaro, F.; Santoro, L.; Turco, R.; Coiifi, R. Sustainable management of water potabilization sludge by means of geopolymers production. J. Clean. Prod. 2019, 229, 1-9. [CrossRef]

53. Novais, R.M.; Carvalheiras, J.; Tobaldi, D.M.; Seabra, M.P.; Pullar, R.C.; Labrincha, J.A. Synthesis of porous biomass fly ash-based geopolymer spheres for efficient removal of methylene blue from wastewaters. J. Clean. Prod. 2019, 207, 350-362. [CrossRef]

54. Chrysochoou, M.; Dermatas, D. Evaluation of ettringite and hydrocalumite formation for heavy metal immobilization: literature review and experimental study. J. Hazard. Mater. 2006, 136, 20-33. [CrossRef] [PubMed]

55. Lasheras-Zubiate, M.; Navarro-Blasco, I.; Fernández, J.M.; Alvarez, J.I. Encapsulation, solid-phases identification and leaching of toxic metals in cement systems modified by natural biodegradable polymers. J. Hazard. Mater. 2012, 233, 7-17. [CrossRef] [PubMed]

56. Mollah, M.Y.A.; Kesmez, M.; Cocke, D.L. An X-ray diffraction (XRD) and Fourier transform infrared spectroscopic (FT-IR) investigation of the long-term effect on the solidification/stabilization (S/S) of arsenic(V) in Portland cement type-V. Sci. Total Environ. 2004, 325, 255-262. [CrossRef] [PubMed]

57. Macias, A.; Kindness, A.; Glasser, F.P. Impact of carbon dioxide on the immobilization potential of cemented wastes: Chromium. Cem. Concr. Res. 1997, 27, 215-225. [CrossRef]

58. Baur, I.; Johnson, C.A. The solubility of selenate-AFt $\left(3 \mathrm{CaO} \cdot \mathrm{Al}_{2} \mathrm{O}_{3} \cdot 3 \mathrm{CaSeO}_{4} \cdot 37.5 \mathrm{H}_{2} \mathrm{O}\right)$ and selenate-AFm $\left(3 \mathrm{CaO} \cdot \mathrm{Al}_{2} \mathrm{O}_{3} \cdot \mathrm{CaSeO}_{4} \cdot \mathrm{xH}_{2} \mathrm{O}\right)$. Cem. Concr. Res. 2003, 33, 1741-1748. [CrossRef]

59. Chen, Q.Y.; Tyrer, M.; Hills, C.D.; Yang, X.M.; Carey, P. Immobilisation of heavy metal in cement-based solidification/stabilisation: A review. Waste Manag. 2009, 29, 390-403. [CrossRef]

60. Zhang, M.; Reardon, E.J. Removal of B, Cr, Mo, and Se from wastewater by incorporation into hydrocalumite and ettringite. Environ. Sci. Technol. 2003, 37, 2947-2952. [CrossRef]

61. Segni, R.; Vieille, L.; Leroux, F.; Taviot-Guého, C. Hydrocalumite-type materials: 1. Interest in hazardous waste immobilization. J. Phys. Chem. Solids 2006, 67, 1037-1042. [CrossRef]

62. Van Jaarsveld, J.G.S.; Van Deventer, J.S.J.; Lorenzen, L. Factors affecting the immobilization of metals in geopolymerized flyash. Metall. Mater. Trans. B 1998, 29, 283-291. [CrossRef]

63. Zhang, J.; Provis, J.L.; Feng, D.; van Deventer, J.S.J. Geopolymers for immobilization of $\mathrm{Cr}^{+}{ }^{,} \mathrm{Cd}_{2}^{+}$, and $\mathrm{Pb}^{+}$. J. Hazard. Mater. 2008, 157, 587-598. [CrossRef] 
64. Palomo, A.; Palacios, M. Alkali-activated cementitious materials: Alternative matrices for the immobilisation of hazardous wastes: Part II. Stabilisation of chromium and lead. Cem. Concr. Res. 2003, 33, 289-295. [CrossRef]

65. Perera, D.S.; Aly, Z.; Vance, E.R.; Mizumo, M. Immobilization of Pb in a Geopolymer Matrix. J. Am. Ceram. Soc. 2005, 88, 2586-2588. [CrossRef]

66. Li, X.; Chen, Q.; Zhou, Y.; Tyrer, M.; Yu, Y. Stabilization of heavy metals in MSWI fly ash using silica fume. Waste Manag. 2014, 34, 2494-2504. [CrossRef]

67. Ma, W.; Chen, D.; Pan, M.; Gu, T.; Zhong, L.; Chen, G.; Yan, B.; Cheng, Z. Performance of chemical chelating agent stabilization and cement solidification on heavy metals in MSWI fly ash: A comparative study. J. Environ. Manag. 2019, 247, 169-177. [CrossRef]

(C) 2019 by the authors. Licensee MDPI, Basel, Switzerland. This article is an open access article distributed under the terms and conditions of the Creative Commons Attribution (CC BY) license (http://creativecommons.org/licenses/by/4.0/). 